Article

\title{
Case Study Comparing Effects of Microplastic Derived from Bottle Caps Collected in Two Cities on Triticum aestivum (Wheat)
}

\author{
Stephan Pflugmacher ${ }^{1}$, Saila Tallinen ${ }^{2}$, Simon M. Mitrovic ${ }^{3}$, Olli-Pekka Penttinen ${ }^{2,4}$, Young-Jun Kim ${ }^{5}$ (D), \\ Sanghun Kim $^{6}$ and Maranda Esterhuizen ${ }^{2,4,5,6, *(D)}$
}

Citation: Pflugmacher, S.; Tallinen, S.; Mitrovic, S.M.; Penttinen, O.-P.; Kim, Y.-J.; Kim, S.; Esterhuizen, M. Case Study Comparing Effects of Microplastic Derived from Bottle Caps Collected in Two Cities on Triticum aestivum (Wheat). Environments 2021, 8, 64 . https: / /doi.org/10.3390/ environments8070064

Academic Editors: Teresa A. P. Rocha-Santos and Joana C. Prata

Received: 4 May 2021

Accepted: 2 July 2021

Published: 6 July 2021

Publisher's Note: MDPI stays neutral with regard to jurisdictional claims in published maps and institutional affiliations.

Copyright: (c) 2021 by the authors. Licensee MDPI, Basel, Switzerland. This article is an open access article distributed under the terms and conditions of the Creative Commons Attribution (CC BY) license (https:// creativecommons.org/licenses/by/ $4.0 /)$.
1 Clayton H. Riddell Faculty of Environment, Earth, and Resources, University of Manitoba, Wallace Building, 125 Dysart Road, Winnipeg, MB R3T 2N2, Canada; Stephan.PflugmacherLima@umanitoba.ca

2 Ecosystems and Environment Research Programme, Aquatic Ecotoxicology in an Urban Environment, Faculty of Biological and Environmental Sciences, University of Helsinki, Niemenkatu 73, 15140 Lahti, Finland; saila.tallinen@kymp.net (S.T.); Olli-Pekka.Penttinen@helsinki.fi (O.-P.P.)

3 School of Life Sciences, University of Technology Sydney, Ultimo, NSW 2007, Australia; Simon.Mitrovic@uts.edu.au

4 Helsinki Institute of Sustainability (HELSUS), Fabianinkatu 33, 00014 Helsinki, Finland

5 Joint Laboratory of Applied Ecotoxicology, Environmental Safety Group, Korea Institute of Science and Technology Europe (KIST Europe), Forschungsgesellschaft mbH, Campus E7 1, Universität des Saarlandes, 66123 Saarbrücken, Germany; youngjunkim@kist-europe.de

6 Center for Chemical Safety Research, Department of Pharmaceutical Science and Technology, Kyungsung University, 309 Suyeong-ro, Nam-gu, Busan 48434, Korea; fatherofdamin@ks.ac.kr

* Correspondence: Maranda.esterhuizen@helsinki.fi; Tel.: +358-503-188-337

\begin{abstract}
As plastic has become an integral component of daily life, microplastic has become a ubiquitous, unavoidable constituent of nearly all ecosystems. Besides monitoring the amount and distribution of microplastic in the environment, it is necessary to understand the possible direct effects, especially toxicity and how it is affected by environmental factors where it is discarded. The present study investigated how microplastic derived from high-density polyethylene bottle caps collected in two climatically different cities, i.e., Singapore (tropical rainforest climate) and Lahti, Finland (continental climate), affected the essential agricultural grain crop, Triticum aestivum (L.). Wheat seedlings were exposed to microplastic derived from these collected bottle caps, as well as new and artificially aged caps, for seven days. Morphological parameters, such as root and shoot length and oxidative stress development, were measured. Exposure to microplastic derived from the caps resulted in reduced seedling root and shoot lengths compared to the controls, as well as enhanced lipid peroxidation and catalase activity. With all parameters tested, microplastic derived from Lahti bottle caps exhibited more severe effects than Singapore, which was similar to that elicited by new microplastic. The Singapore microplastic had possibly leached its toxic substances before collection due to accelerated degradation promoted by the prevailing warmer climate conditions.
\end{abstract}

Keywords: microplastic; polyethylene; weather; heat; plastic pollution

\section{Introduction}

The potential hazardousness of microplastics (MP) in ecosystems has been recognized, which has increased interest in understanding the impact and influencing factors [1]. This is a global issue, as plastic debris, or more precisely MP particles $(<5 \mathrm{~mm}$ [2]), have been detected worldwide, including remote and pristine areas such as the arctic or high mountain areas [3-5].

Plastic or polymer degradation in the environment is a long-term, continuous, and complex process. Chemical changes in the polymer structure will manifest in different ways, mainly depending on the degradation state in which the plastic already is [6]. 
Environmental factors such as light, heat, rain, snow/ice, moisture, as well as chemical and biological activities, are involved in the deterioration or embrittlement of polymers and thus the plastic material as a whole. During exposure to these factors, the functionality of the polymer is affected, e.g., by bond scissions and other chemical transformations of the polymer structure [7]. Primarily, weathering is involved in the formation of secondary MP particles, and therefore, this process depends on factors closely linked to climate conditions.

Kulshreshtha et al. [6] suggested categorizing polymer degradation processes as thermal, photo-oxidative/radiation, mechanical, hydrolytic and acid, chemical, and biological processes. Thermal processes such as heating cause changes in the polymer structure due to elevated temperatures and are initiated without the involvement of other chemical compounds. Scissions in the polymer backbone will occur randomly or at the polymer chain end. Radiation, such as UV light in the range of 280 to $400 \mathrm{~nm}$, can break C-C bonds when 70 to $100 \mathrm{kcal} \mathrm{mol}^{-1}$ energy is involved [7-9]. Sunlight, the source of radiation in nature, also is correlated with heat increase on the surface and inside plastic material [10]. The build-up of internal heat in the plastic might lead to the induction of thermo-oxidative processes leading to further deterioration or embrittlement of the plastic material [11].

In addition, mechanical processes in nature, such as wave action in aquatic environments and other forms of abrasion, cause plastics to deteriorate via physical forces, e.g., shear forces. Hydrolytic processes and acid conditions can cause polymer chain scissions because of hydrolysis working on sensitive functional groups of the main chain in moist and acid conditions of the surrounding environment. In parallel, high humidity is known to accelerate the degradation rate of plastics mainly by supporting the leaching process of stabilizing additives with small water quantities, a process similar to hydrolysis [9]. Chain scissions and oxidation are initiated in the polymer through chemical processes brought about by gases (ozone, in general, atmospheric pollutants) or corrosive chemicals (nitric-, sulfuric-, or hydrochloric acids). Depending on the polymer itself, it may also be subjected to biological action by bacteria, fungi, or enzymes, which will degrade the polymer by working on functional groups, mainly stabilizers or plasticizers. Plastic debris in the environment eventually will be covered by an active biofilm, which initiates so-called fouling. Fischer et al. [12] postulated that with increased biofilm cover, light availability would be reduced and therefore, as a result, the photo-degradation of the plastic debris might be reduced [13]. Thus, it is probable that the prevailing ambient conditions may affect the decomposition and leaching of MP and, ultimately, its toxicity and the threat posed to its immediate environment.

The purpose of the present study was to determine whether MP derived from bottle caps that were new, aged and collected in the environment in two climatically different cities elicited varying phytotoxicity. Therefore, two cities with different climate conditions were chosen from which material was collected: Singapore, classified according to the Köppen-Geiger classification system [14,15] as Af (tropical rainforest climate), and the city of Lahti in Finland, classified as Dfb (continental climate). Bottle caps were collected from different parks in Singapore and Lahti, Finland. These bottle caps were made of high-density polyethylene (HDPE), chemically expressed as $\mathrm{CnH}_{2} \mathrm{n}$, which is, in general, a linear molecule with minimal branching [16]. The caps were marked with the Resin Identification Code (RIC), which was introduced in 1988 by the US Society of the Plastics Industry, with three arrows in a triangle shape exhibiting No. 2 or 02 in the middle and "HDPE" or "PE-HD" typically is written under the sign. HDPE is among the two most commonly used polymer types [16].

Internationally, wheat (Triticum aestivum L.) is one of the chief crops and is known to be remarkably adaptable to different environmental conditions, making it a global food staple [17]. The exposure of agriculturally important plants to MP deposited in the soil from various sources such as stormwater and road runoff, sludge use, and wastewater irrigation will most likely increase as MP pollution increases [18]. If the plants experience adverse effects, it may also influence the yield, leading to economic losses and, in the long 
term, even worsening the food crisis. Based on its economic importance and function as sustenance, wheat was selected as the plant subject in this study.

This study aimed to investigate the adverse effects of MP from discarded bottle caps, collected from two climatically different cities, on wheat in terms of growth and its cellular oxidative status to understand the effects of climate conditions on the ecotoxicity of the material. For this purpose, four treatments, i.e., new bottle caps, artificially aged new caps, and bottle caps collected in Singapore and the city of Lahti in Finland, respectively, were used. These were assessed against controls evaluating their effects on seedling development as morphological effect (root and shoot length) and lipid peroxidation and antioxidative enzyme catalase activity as physiological effects.

\section{Materials and Methods}

\subsection{Microplastic}

Four different batches of caps were used: (1) new caps, (2) artificially aged new caps, (3) caps collected in the city of Lahti, Finland, and (4) caps collected in the city-state Singapore, Republic of Singapore. According to the Köppen-Geiger classification system, Singapore is classified as Af (tropical rainforest climate) and the city of Lahti in Finland as Dfb (continental climate) $[14,15]$. Detailed descriptions of the climate parameters are given in Table 1.

Table 1. Comparison of climate data from Singapore and Lahti (climate-data.org).

\begin{tabular}{|c|c|c|}
\hline & Singapore & Lahti \\
\hline \multirow{3}{*}{ Ave temperature $\left[{ }^{\circ} \mathrm{C}\right]$} & 26.7 & 5.2 \\
\hline & $\min 25.8$ (January) & $\min -6.3$ (January) \\
\hline & $\max 27.4$ (May) & $\max 18$ (July) \\
\hline Ave temperature variation $\left[{ }^{\circ} \mathrm{C}\right]$ & 1.3 & 24.3 \\
\hline Sunshine [Ave $\mathrm{h} \mathrm{yr}^{-1}$ ] & 2064 & 1860 \\
\hline UV-Index & $7-9$ & $1-5$ \\
\hline Precipitation $\left[\mathrm{mm} \mathrm{yr}^{-1}\right]$ & 2366 & 691 \\
\hline Acidity $[\mathrm{pH}]$ & 4.2 & 5.5 \\
\hline Rain [Days yr ${ }^{-1}$ ] & 102 & 206 \\
\hline Humidity [\%] & 84 & 80 \\
\hline \multirow{2}{*}{ Köppen-Geiger classification } & Af & $\mathrm{Dfb}$ \\
\hline & tropical rainforest climate & continental climate \\
\hline
\end{tabular}

Bottle caps were collected in Singapore the first week of September 2018 and the second week of September 2018. Bottle caps were collected indiscriminately by walking through all major parks in these cities for one week (about 2 to $3 \mathrm{~h}$ a day) and collecting all bottle caps seen into a cotton bag. All caps were washed with tap water to remove adherent dirt particles and dried at room temperature. Blue threaded bottle caps only were used for all experiments. Except for shredding, the bottle caps were not further cleaned or processed to retain them in the same condition as they were when collected.

Accelerated ageing of new threaded bottle caps was performed according to Fejdyś et al. [19], making use of PN-EN 12280-1:2002 [20] before shredding into MP. In short, artificial ageing was performed in a thermal chamber (TK 720 Binder $\mathrm{GmbH}$, Tuttlingen, Germany) with a heating effect at a temperature of $70{ }^{\circ} \mathrm{C} \pm 0.5^{\circ} \mathrm{C}$ and a humidity of $0 \pm 1.5 \%$ for 80 days.

A desktop plastic recycler (SHR3D IT, 3devo B.V. Utrecht, The Netherlands) with a sieve size of $4 \mathrm{~mm}$ was used to prepare the MP granulate from the different batches of threaded bottle caps. To reach the desired granulate size, the material was applied to the shredder five times. The MP particles obtained were irregular fragments $\leq 4 \mathrm{~mm}$.

\subsection{Wheat Plant Cultivation}

Wheat (Triticum aestivum L. Variant: Taifun M) seeds (Ecocontrol, Osterrode, Germany) were allowed to imbibe in standard medium $\left(900 \mathrm{mg} \mathrm{L}^{-1} \mathrm{KNO}_{3}, 900 \mathrm{mg} \mathrm{L}^{-1} \mathrm{Ca}\left(\mathrm{NO}_{3}\right)_{2}\right.$, 
$360 \mathrm{mg} \mathrm{L}^{-1} \mathrm{MgSO}_{4}, 200 \mathrm{mg} \mathrm{L}^{-1} \mathrm{KH}_{2} \mathrm{PO}_{4}, 40 \mathrm{mg} \mathrm{L}^{-1}$ Fe-EDTA and micronutrients: $1 \mathrm{mg}$ $\mathrm{L}^{-1} \mathrm{MnSO}_{4}, 0.2 \mathrm{mg} \mathrm{L}^{-1} \mathrm{CuSO}_{4}, 0.2 \mathrm{mg} \mathrm{L}^{-1} \mathrm{ZnSO}_{4}, 1.8 \mathrm{mg} \mathrm{L}^{-1} \mathrm{H}_{3} \mathrm{BO}_{3}, 3.4 \mathrm{mg} \mathrm{L}^{-1}$ $\left(\mathrm{NH}_{4}\right)_{6} \mathrm{Mo}_{7} \mathrm{O}_{24}$, and $\left.9 \mathrm{mg} \mathrm{L}^{-1} \mathrm{CoCl}_{2}\right)$ for $1 \mathrm{~h}$ [21]. Afterwards, the seeds were disinfected first using $0.1 \%$ Tween 80 solution $(w / w), 0.5 \%$ sodium hypochlorite $(w / w)$, and finally $0.75 \%$ hydrogen peroxide solution $(w / w)$ and washed between these steps with distilled water. For germination, the seeds were transferred onto filter paper (Whatman No. 1), wetted with the standard medium in sterile Petri dishes, and incubated at room temperature $\left(21^{\circ} \mathrm{C}\right)$ in the dark for $24 \mathrm{~h}$. The seed batch used for all experiments exhibited a germination rate of $98 \% \pm 1 \%$. Seeds, from which the primary root protruded after $48 \mathrm{~h}$, were transferred in single to reagent tubes filled with soil. Turf-free soil was purchased from MeinWoody (Grub am Forst, Germany) and consisted of 20\% lingo fibers, 35\% cocopeat washed, 10\% spelt fermented, and 35\% substrate compost. The soil had a pH of between $5.85 \pm 0.04$.

\subsection{Exposure Scenarios}

Controls contained soil only, and for exposures to the different batches of MP, the soil was premixed with $2 \%(w / w)$ of the derived MP granulate in replicates of eight. Highly contaminated soils can exhibit an MP amount of up to 7\% [22]. The amount used in these experiments was, therefore, on the lower environmental level. The soil was prepared with the respective plastic material before separating into the individual exposure sets. For each exposure set, eight independent replicates with 50 seeds each were used, so in total, for each exposure set, 400 seeds per treatment. The seeds were grown at $24{ }^{\circ} \mathrm{C} \pm 1{ }^{\circ} \mathrm{C}$ under a light intensity of 1500 lux and a light-dark cycle of $14: 10 \mathrm{~h}$ for seven days before evaluation. During all exposure, care was taken to avoid introducing foreign MP into the experiments [23].

\subsection{Measurement of Root and Shoot Length}

The length of the seedlings' roots and shoots were manually measured after seven days of germination in centimeter $(\mathrm{cm})$ with a digital caliper. Plants were carefully removed from the glass vial, and the roots were washed with water to remove soil and plastic particles before measurement.

\subsection{Oxidative Stress Status}

\subsubsection{Measurement of Lipid Peroxidation}

Lipid peroxidation (LPO) was measured according to Botsoglou et al. [24] as the amount of malondialdehyde (MDA), an end-product of unstable and decomposing lipid peroxides. The reaction between the chromogenic reagent, $\mathrm{N}$-methyl-2-phenylindole and MDA results in a stable chromophore with maximum absorbance at $586 \mathrm{~nm}$. Roots and shoots of T. aestivum seedlings ( $0.5 \mathrm{~g})$ were homogenized in $20 \mathrm{mM}$ phosphate buffer $\mathrm{pH}$ 7.4. Then, $10 \mu \mathrm{L}$ of butylated hydroxytoluene (BHT) was added to prevent sample oxidation. The precipitate was removed by centrifugation for $10 \mathrm{~min}$ at $3000 \times \mathrm{g}$ at $4{ }^{\circ} \mathrm{C}$. The supernatant was used for the assay and protein determination. MDA in the sample was assessed by gently mixing $200 \mu \mathrm{L}$ of the sample with $600 \mu \mathrm{L}$ of N-methyl-2-phenyl-indole in acetonitrile. Then, $150 \mu \mathrm{L}$ of $12 \mathrm{~N} \mathrm{HCl}$ was added, mixed, and incubated for $1 \mathrm{~h}$ at $45^{\circ} \mathrm{C}$. Samples were centrifuged at $15,000 \times g$ for $10 \mathrm{~min}$, and the clear supernatant was measurement at $586 \mathrm{~nm}$ [25]. A calibration curve was established using MDA.

\subsubsection{Measurement of Catalase Activity}

Plant extracts (roots and shoots separately) were prepared according to Stüven and Pflugmacher [25] with slight modifications. A total of $5 \mathrm{~g}$ of plant material (wet weight) was used in four sets with five independent replicates each. The plant material was ground in liquid nitrogen to a fine powder using a mortar and pestle, transferred to $0.1 \mathrm{M}$ sodium phosphate buffer ( $\mathrm{pH}$ 6.5) containing $14 \mathrm{mM}$ dithioerythritol and $5 \mathrm{mM}$ EDTA. Further homogenization was performed in a glass homogenizer on ice. The resulting slurry was stirred on a magnetic plate stirrer on ice for $30 \mathrm{~min}$ and then centrifuged at 
$5000 \times g$ for $5 \mathrm{~min}$. Soluble proteins were concentrated by ammonium sulfate precipitation to $80 \%$ saturation. After a second centrifugation step at $25,000 \times \mathrm{g}$ for $30 \mathrm{~min}\left(4^{\circ} \mathrm{C}\right)$, the resulting pellet contained the soluble proteins. The pellet was suspended in $20 \mathrm{mM}$ sodium phosphate buffer ( $\mathrm{pH}$ 7.0) and desalted by gel filtration on NAP-10 columns (Amersham Pharmacia, Uppsala, Sweden) before enzyme measurement.

The protein content of each sample was determined according to Bradford [26] using the Bradford protein dye reagent (Sigma). Bovine serum albumin (98\%, Sigma) was used as a standard protein to calibrate the assay method. Catalase (CAT) activity was spectrophotometrically measured according to Aebi et al. [27] and expressed as $\mu \mathrm{kat} \mathrm{mg}^{-1}$ protein.

\subsection{Statistical Tests}

IBM $^{\circledR}$ SPSS $^{\circledR}$ statistics 25 (2018) was used to perform a descriptive analysis based on the mean of the different endpoints chosen. Results are expressed as mean \pm standard deviation (SD). The homogeneity and normality of the data were assessed employing histograms and Levene's test of homogeneity. As all data sets resulted in a significant Levene's test $(p<0.05)$, the non-parametric Kruskal-Wallis test was used with pair-wise comparison to identify statistical differences between datasets [28]. Following Bonferroni adjustment, an alpha value of 0.05 was set to distinguish significance between treatments.

\section{Results and Discussion}

\subsection{Length of Root and Shoot}

Pre-germinated wheat (T. aestivum L.) seedlings were cultivated for seven days in soil containing $2 \%$ MP particles $(\leq 4 \mathrm{~mm}, w / w)$ derived from four different bottle caps batches, i.e., new, aged, collected from Lahti and Singapore. The root length of T. aestivum grown in soil containing MP derived from new bottle caps was inhibited by $60 \%(p<0.001)$ (Figure 1A). With artificially aged MP present in the soil, root length was reduced by $14 \%$ compared to untreated controls $(p<0.001)$. The roots of seedlings cultivated in soil containing MP from bottle caps collected in Lahti showed an inhibitory effect of $49 \%$ $(p<0.001)$, whereas those collected in Singapore inhibited the root growth by $7 \%(p<0.001)$, which is statistically the same inhibition as caused by the aged MP $(p=1)$.

T. aestivum, as a monocotyledon, has a fibrous root system, which is characterized by numerous roots with similar diameters emerging from the stem's base. A fully functioning root system is essential for plants to thrive and for agricultural crops like wheat to achieve the expected crop yield [29]. Root growth can be affected by internal as well as environmental parameters [30]. A disturbance in root development and growth at an early stage of plant life determines its further growth and development. The uptake of water and nitrogen in its nitrate form is positively correlated with long roots and vigorous root growth [31]. Therefore, in the shorter roots of MP exposed T. aestivum, water and nitrate uptake might be impaired, influencing the shoot growth. Root morphology was visibly changed (Figure 2), exhibiting overall shorter root systems, and in the case of exposure to Lahti derived MP, a drastically reduced root system was seen (Figure 2B).

A similar pattern was observed regarding the shoot development of the seedlings (Figure 1B) with the maximum growth reduction (69\%) induced by exposure to MP from new bottle caps $(p<0.001)$, followed by the bottle cap material collected in Lahti which resulted in $45 \%$ inhibition $(p<0.001)$. Wheat seedlings exposed to artificially aged plastic and MP derived from Singaporean bottle caps exhibited shoot growth reduced by $18 \%$ $(p<0.001)$ and $11 \%(p<0.001)$, respectively; however, comparing the inhibition between artificially aged and Singapore MP was statistically similar $(p=0.058)$. In general, the new MP resulted in the most compromised root and shoot growth, followed by the inhibition seen with Lahti MP, with the lowest inhibition seen with Singapore and artificially aged MP. 

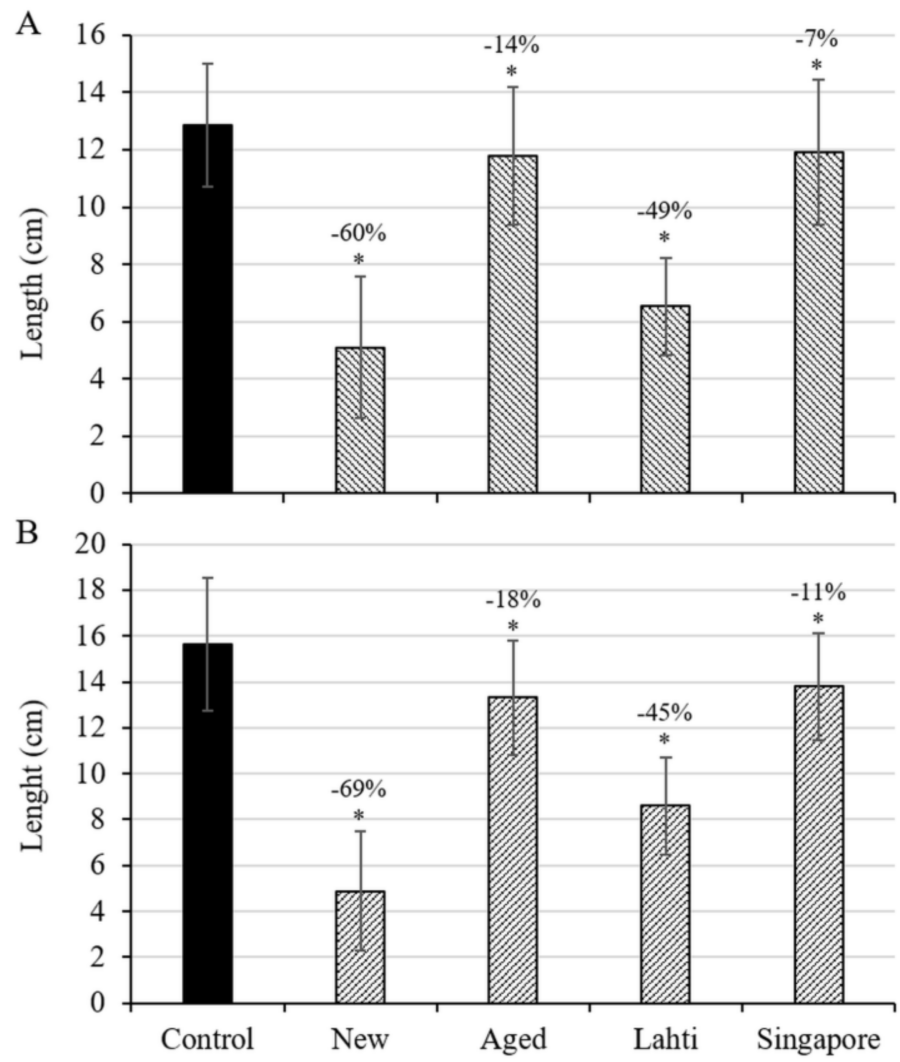

Figure 1. Average root (A) and shoot length (B) of T. aestivum seedlings exposed to $\leq 4 \mathrm{~mm}$ microplastic derived from treated bottle caps (new, artificial aged, caps collected in Lahti and Singapore) in the soil after seven days of exposure compared to controls without microplastic in soil. Data represent mean length \pm standard deviation and significance compared to the control is represented by an asterisk $\left.{ }^{*}\right)$ where $p<0.05(n=400)$.

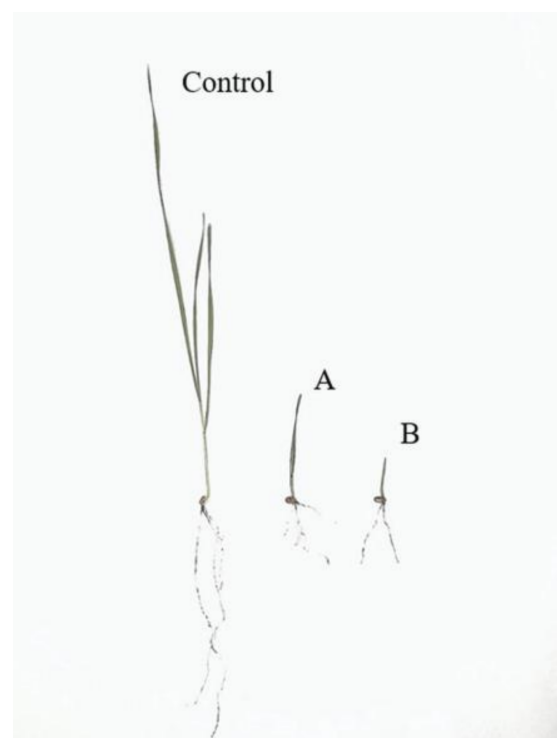

Figure 2. Seedling morphology of T. aestivum seedlings exposed to $2 \%$ microplastic derived from bottle caps from (A) Singapore and (B) Lahti in the soil for seven days compared to a control.

A correlation between the root and shoot growth was established by Liao et al. [32] and Palta et al. [33] as adverse effects on the root development would undoubtedly impact the shoot growth due to a reduced capacity for taking up of the necessary nutrients and water 
required for optimal growth. As seen in the presented data, reduced root development was matched by shorter shoots, probably as the roots were unable to meet the nutrient and water demand to sustain typical growth. Exposure to MP in the soil, therefore, could lead to possible reduced crop yield as plants would be underdeveloped as a result of inhibited root growth.

\subsection{Oxidative Stress Status}

Oxidative stress can be assessed by measuring lipid peroxidation, i.e., destruction of membranes by reactive oxygen species (ROS). This three-step process is initiated by the hydroxyl radicals reacting with polyunsaturated fatty acids yielding a peroxy radical. The radical initiates a chain reaction and forms unstable lipid hydroperoxide, which undergoes a Fenton reaction in the presence of $\mathrm{Fe}$, resulting in a reactive alkoxy radical. Among the degradation products of lipid hydroperoxides is MDA. In the present study, wheat seedlings exposed to MP generated from new plastic bottle caps for seven days showed a significant increase of MDA in roots by $91 \%(p<0.001)$ (Figure 3A). The MDA concentration in the roots of seedlings exposed to MP from the bottle caps collected from Lahti increased by $47 \%(p<0.001)$. However, exposure to artificially aged MP and MP from Singapore did not affect the MDA concentration in the roots $(p=1)$.

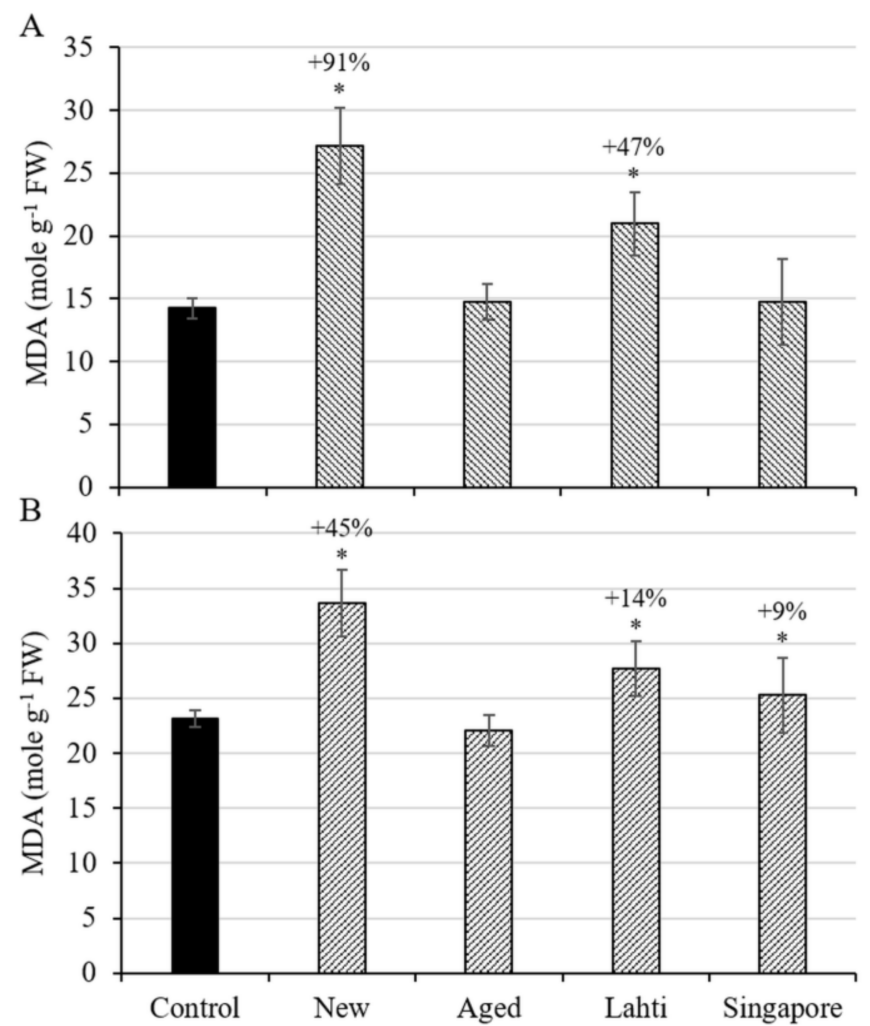

Figure 3. Lipid peroxidation expressed by the concentration of malondialdehyde (MDA) in roots (A) and shoots (B) of T. aestivum seedlings exposed to $\leq 4 \mathrm{~mm}$ microplastic particles from threaded bottle caps (new, artificially aged caps collected in Lahti and Singapore) in the soil for seven days compared to controls without microplastic in soil. Data represent mean MDA \pm standard deviation. Significance compared to the control is represented by an asterisk $\left({ }^{*}\right)$ where $p<0.05(n=400)$.

The MDA patterns in wheat shoots (Figure 3B) with different exposures were similar to the results obtained for the roots, showing the most considerable increase in exposures with new bottle caps $(45 \%, p<0.001)$, followed by Lahti cap MP $(14 \%, p<0.001)$, and only marginal increase with Singapore cap MP $(9 \%, p=0.008)$. No MDA increase was observed in seedlings exposed to artificially aged caps $(p=1)$. 
Oxidative stress is combated in plants by increasing the expression and activity of the antioxidative enzymes [34]. Catalase is one of the enzymes involved in detoxifying hydrogen peroxide in cells by conversion to water. The catalase activity in wheat roots (Figure 4A) grown for seven days in soil containing MP derived from the new cap was enhanced by $139 \%(p<0.001)$ and with MP material from Lahti caps by $91 \%(p<0.001)$. Using the Singapore material, the enzyme activity increased by $51 \%$ compared to the control $(p<0.001)$; however, no effect was observed with exposure to the artificially aged plastic caps $(p=0.234)$.
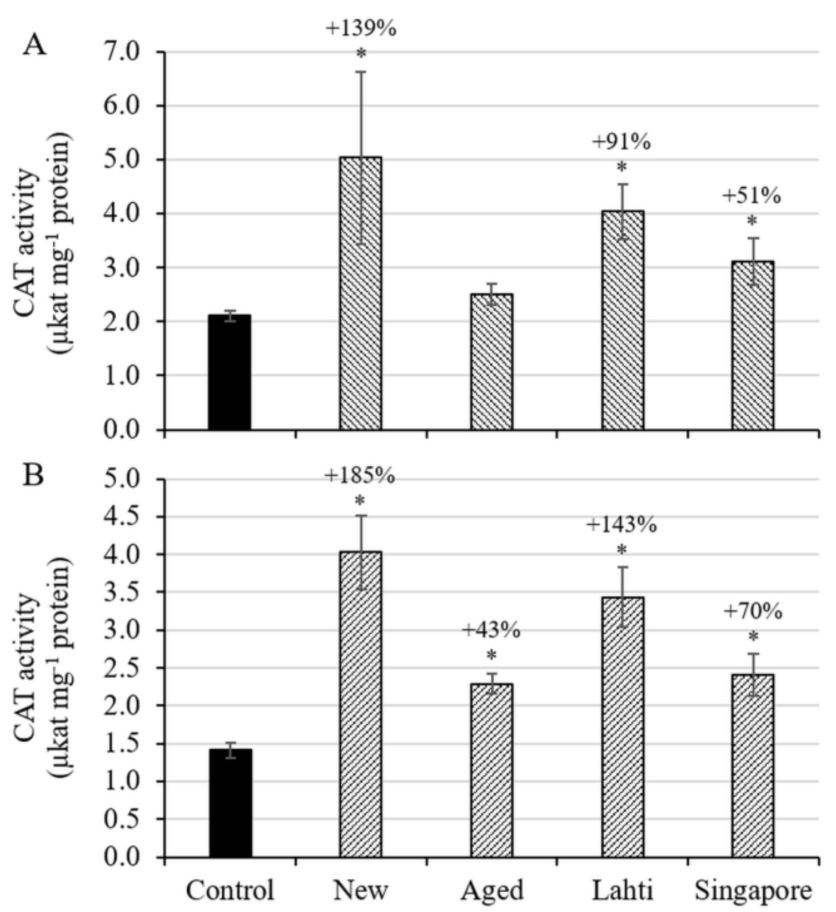

Figure 4. The catalase activity in roots (A) and shoots (B) of T. aestivum seedlings exposed to $\leq 4 \mathrm{~mm}$ microplastic particles from threaded bottle caps (new, artificial aged, collected in Lahti and Singapore) in the soil after seven days compared to controls without microplastic in soil. Data represent mean enzyme activities \pm standard deviation. Statistical significance compared to the control is represented by an asterisk $\left(^{*}\right)$ where $p<0.05(n=400)$.

In the shoots (Figure $4 \mathrm{~B}$ ), a similar catalase activity pattern was seen with an increase of $185 \%$ using the new plastic material $(p<0.001)$ and $143 \%$ with Lahti-derived material $(p<0.001)$. Lesser increases in the catalase activity were measured with exposure to the Singapore material ( $70 \%$ elevation, $p=0.004)$ and artificially aged material ( $43 \%$ elevation, $p=0.022)$.

Free radicals may be present in plastics as by-products of polymerization, additives, or contaminants [35]. Bond breakage during degradation also results in the release of free radicals [36]. In exposed organisms, free radicals will be converted to ROS [37], leading to elevated oxidative stress. Induction of oxidative stress by MP has been detected in the plant Lepidium sativum [38], as well as several animals such as juvenile crabs Eriocheir sinensis [39], the bivalve Corbicula fluminea [40], and juvenile fish Dicentrarchus labrax [41], showing lipid peroxidation and enhancement of catalase and other antioxidative stress enzyme activities.

From the data presented here, it can be deduced that oxidative stress occurred in the wheat seedlings exposed to MP from new and Lahti caps, and a lesser extent, with caps from Singapore but not artificially aged caps. ROS signaling in plants can be disturbed greatly by oxidative stress posed by external factors [42]. UPBEAT1 transcription factor, which regulates cell proliferation and differentiation in root tips, is regulated by ROS [43]. Other internal factors, including phytohormones such as auxin, are known as central regulators 
of root development [44]. Thus, the increased oxidative stress strongly contributed to the reduced root development observed, which consecutively affected shoot development.

\subsection{Potential Relationship between MP Toxicity and Environmental Factors}

In the present study, the presence of MP in the soil led to adverse effects in the agriculturally important crop plant T. aestivum, although to different degrees depending on their origin, i.e., new, aged, from Lahti, or from Singapore. The factors accounting for these varying effects are not yet known, and there are a multitude of factors that could contribute to the toxicity of the MP such as the diversity of possible microbes present in biofilms that form on the caps, the ink used, water hardness, time since discarding and so on. Concerning MP in soil, it is clear that changes in soil structure and biodiversity, as well as aggregate formation, are expected $[45,46]$. For example, less than $2 \%$ of the polyester microfibers present in soil can destabilize soil aggregates [45,47]. However, climate and ageing factors could play a role, as different responses were observed with exposure to the same MP concentration from the two cities, and even compared to new and artificially aged MP. Under the assumption that the loss of physical integrity of polymers might open ways that, e.g., plastic additives (pigments, flame retardant, plasticizers or stabilizers) could leach out more readily and more rapidly [48], the climate parameters prevailing in the two cities were considered.

In plastics, elevated temperature causes structural changes due to scission in the polymer chain backbone, the so-called thermal or thermos-oxidative processes [49]. Polyethylene is known to be very susceptible to thermal degradation due to its chemical structure [50]. Lahti has an average yearly temperature of $5.2^{\circ} \mathrm{C}$, which is $21.5^{\circ} \mathrm{C}$ lower than Singapore's average yearly temperature (Table 1 , climate-data.org). Due to this temperature difference, it is conceivable that plastic material littered in Singapore might deteriorate faster than plastic littered in Lahti, both because of elevated temperature and because of heat accumulation. Considering the different temperature profiles between the two cities (Table 1), the highest temperature a plastic piece in Singapore could be exposed to, on average, is $27.4^{\circ} \mathrm{C}$, which could be enhanced by internal heat accumulation. However, a thermal energy of even, e.g., $50{ }^{\circ} \mathrm{C}$, corresponds to only $22.68 \mathrm{kcal} \mathrm{mol}^{-1}$, which is insufficient to cause bond cleavage [8]. Accelerated degradation of plastic in Singapore becomes plausible when considering the effect of sunlight in conjunction with heat. The energy of UV-light varies between 228 and $647 \mathrm{KJ} \mathrm{m}^{-2}$, the typical energy necessary to break carbon-carbon bonds is $347 \mathrm{KJ} \mathrm{mol}^{-1}$, for carbon-hydrogen bonds, this is around $413 \mathrm{KJ} \mathrm{mol}^{-1}$, and for double carbon-carbon bonds around $607 \mathrm{KJ} \mathrm{mol}^{-1}$ [7-9]. Bond breaking goes hand in hand with the formation of free radicals (carboxyl and carbonyl structures), which lead to overall shorter polymer chains. Further degradation occurs through the attachment of oxygen to the broken sites [36]. As Singapore has more sunlight per year and a higher UV index, this would accelerate plastic degradation.

Internal heat accumulation due to sunlight is a contributing factor in the photooxidative process as well. The high UV index, as well as the visible part of the sunlight (400 to $760 \mathrm{~nm}$ ), also leads to parallel heat accumulation in the plastic and enhanced ageing and deterioration by accelerated thermal oxidation [7,51]. Thus, it is possible that accelerated degradation leads to faster leaching of additives and thus reduced toxicity of the MP generated from bottle caps from a warmer, sunnier climate, as seen in the current study. However, all processes involving sunlight have the premise that the plastic must be freely exposed, making the scenario more likely in an aquatic environment than in soil, especially when the plastic material is broken down to MP and mixed in or is covered by soil [52]. The influence of biofilms should be considered, as well. According to Fischer et al. [12], a biofilm on plastic acts like sun protection against UV light penetration and may slow down the deterioration process. However, information regarding biofilms on plastics is scarce.

Additionally, Lahti is covered with snow and ice three to five months of the year. Dry ice and snow cover will not enhance the moisture in the plastic and, therefore, hydrolysis effects, meaning a slowing-down effect on the degradation process of plastics under snow 
cover [8]. Considering precipitation, Lahti has $691 \mathrm{~mm}$ per year, which is 3.4 times lower than the average precipitation in Singapore. Singapore also experiences rainy days more often than Lahti. However, the acidity of the rain might play a role as well, and the degradation may be accelerated in a more acidic environment. In Singapore, rainwater has an average $\mathrm{pH}$ of 4.2 compared to Lahti, with a $\mathrm{pH}$ of 5.5 .

Considering all of the climate parameters that may influence plastic deterioration and leaching, Singaporean plastic litter is more prone to leaching because of the prevailing climate conditions, which is supported by our findings, i.e., that the toxicity of bottle caps collected from Singapore is lower, as the climate-induced faster degradation and leaching of toxic chemical substances. Pflugmacher et al. [53] previously demonstrated that the toxicity of polycarbonate to Lepidium satioum decreased with extended ageing time, suggesting that the hazardous chemicals causing the toxicity may leach out as a function of time.

Naturally, the overall toxicity of the plastic is not reduced; only the release with time is altered depending on the environmental factors to which it is exposed. With the same concentration of HDPE MP, from the same manufacturer, the starting potential toxicity is the same. However, the plastic material loses its toxic properties faster with time in Singapore than in Lahti. From the moment the plastic litter is discarded until complete decomposition, the environment suffers the same toxic consequences, but on a different timeline depending on the impact of climate. The MP from bottle caps collected in Singapore displayed reduced toxicity in the present study, possibly due to prior leaching of the toxic additives.

\section{Conclusions}

MP has become ubiquitous in all ecosystem compartments and is a part of the soil all over the world. This research shows that MP influences plant root and shoot growth and promotes oxidative stress. The toxicity of plastic litter such as bottle caps is different when collected in Singapore from when collected in Lahti. Climate conditions possibly influenced the phytotoxicity of the plastic material seen in the present study, as they could have promoted faster leaching of toxic compounds into the environment, causing a reduced effect in the current study. In agreement with this, experiments run with artificially aged bottle caps showed that adverse effects were not significantly different from the controls. More work is needed to elucidate the possible adverse effects of MP and aged plastic in our environment. The results indicate that the presence of MP in agricultural soils may impact plant growth and development and thus impact crop yields.

Author Contributions: Conceptualization, S.P., S.T., S.M.M., Y.J.K., O.-P.P., S.K. and M.E.; methodology, S.P., M.E.; validation, S.P., M.E.; formal analysis and investigation, S.P., S.T., O.-P.P., and Y.J.K.; resources, S.P., M.E.; data curation, S.P., M.E.; writing—original draft preparation, S.P., M.E.; writingreview and editing, All; supervision, S.P., M.E.; project administration, S.P., M.E.; funding acquisition, S.P., M.E., Y.J.K. All authors have read and agreed to the published version of the manuscript.

Funding: This research was partly funded by the Joint Laboratory of Applied Ecotoxicology, KIST Europe's National Research Council of Science \& Technology (NST) grant by the Korea government (MSIP) (No. CAP-17-01-KIST Europe) and the starting grant of the University of Helsinki for the new Professorship of Aquatic Ecotoxicology in an Urban Environment funded by the city of Lahti. Open access funding provided by University of Helsinki.

Data Availability Statement: The data that support the findings of this study are available from the corresponding author upon reasonable request.

Conflicts of Interest: The authors declare no conflict of interest.

\section{References}

1. Vethaak, A.D.; Legler, J. Microplastics and human health. Science 2021, 12, 672-674. [CrossRef]

2. Arthur, C.; Baker, J.; Bamford, H. Proceedings of the International Research Workshop on the Occurrence, Effects, and Fate of Microplastic Marine Debris, Tacoma, WA, USA, 9-11 September 2008; NOAA Marine Debris Division: Silver Spring, MD, USA, 2008 ; p. 530. 
3. Dris, R.; Gasperi, J.; Rocher, V.; Saad, M.; Renault, N.; Tassin, B. Microplastic contamination in an urban area: A case study in Greater Paris. Environ. Chem. 2015, 12, 592-599. [CrossRef]

4. Allen, S.; Allen, D.; Phoenix, V.R.; Le Roux, G.; Jiménez, P.D.; Simonneau, A.; Binet, S.; Galop, D. Atmospheric transport and deposition of microplastics in a remote mountain catchment. Nat. Geosci. 2019, 12, 339-344. [CrossRef]

5. Scopetani, C.; Chelazzi, D.; Cincinelli, A.; Esterhuizen-Londt, M. Assessment of microplastic pollution: Occurrence and characterisation in Vesijärvi lake and Pikku Vesijärvi pond, Finland. Environ. Monit. Assess. 2019, 191, 652. [CrossRef]

6. Kulshreshtha, A.K. Chemical degradation. In Handbook of Polymer Degradation; Hamid, S.H., Amin, M.B., Maadhah, A.G., Eds.; Taylor \& Francis: Oxford, UK, 1992; pp. 55-94.

7. Shah, A.A.; Hasan, F.; Hameed, A.; Ahmed, S. Biological degradation of plastics: A comprehensive review. Biotech. Adv. 2008, 26, 246-265. [CrossRef] [PubMed]

8. Kamal, M.R. Cause and effect in the weathering of plastics. Polym. Eng. Sci. 1970, 10, 108-121. [CrossRef]

9. Davis, A.; Sims, D. Weathering of Polymers; Springer Science \& Business Media: London, UK, 1983.

10. Rabinovitch, E.; Queensbury, G.J.; Summers, J.W. Predicting heat build-up due to the sun's energy. J. Vinyl. Addit. Technol. 1983, 5, 110-115. [CrossRef]

11. Andrady, A.L. Proceedings of Symposium on Degradable Plastics, Washington, DC, USA, 10 June 1987; Society of Plastics Industry: Washington, DC, USA, 1987; pp. 22-25.

12. Fischer, C.E.; Castelli, V.J.; Rodgers, S.D.; Bleile, H.R. Technology for control of marine biofouling. In Marine Biodeterioration: An Interdisciplinary Study; Costlow, J.D., Tipper, R.C., Eds.; Naval Institute Press: Annapolis, MD, USA, 1984; pp. 261-300.

13. Cooper, D.A.; Corcoran, P.L. Effects of mechanical and chemical processes on the degradation of plastic beach debris on the island of Kauai, Hawaii. Mar. Pollut. Bull. 2010, 60, 650-654. [CrossRef]

14. Köppen, W. Die Wärmezonen der Erde, nach der Dauer der heissen, gemässigten und kalten Zeit und nach der Wirkung der Wärme auf die organische Welt betrachtet (The thermal zones of the earth according to the duration of hot, moderate and cold periods and to the impact of heat on the organic world). Meteorol. Z 1884, 1, 215-226, Translated and edited by Volken, E., Ronnimänn, S.B. Meteorol. Z. 2011, 20, 351-360.

15. Geiger, R. Klassifikation der Klimate Nach W. Köppen (Classification of Climates after W. Köppen). Landolt-Börnstein-Zahlenwerte und Funktionen aus Physik, Chemie, Astronomie, Geophysik und Technik, Alte Serie 3; Springer: Berlin/Heidelberg, Germany, 1954; pp. 603-607.

16. Arutchelvi, J.; Sudhakar, M.; Arkatkar, A.; Doble, M.; Bhaduri, S.; Uppara, P.V. Biodegradation of polyethylene and polypropylene. Indian J. Biotech. 2008, 7, 9-22.

17. Shewry, P.R. Wheat. J. Exp. Bot. 2009, 60, 1537-1553. [CrossRef] [PubMed]

18. He, D.; Luo, Y.; Lu, S.; Liu, M.; Song, Y.; Lei, L. Microplastics in soils: Analytical methods, pollution characteristics and ecological risks. TrAC Trends Anal. Chem. 2018, 109, 163-172. [CrossRef]

19. Fejdyś, M.; Landwijt, M.; Strusczyk, M.H. Effects of accelerated ageing conditions on the degradation process of dyneema ${ }^{\circledR}$ polyethylene composites. Fibres Text East Eur. 2011, 19, 60-65.

20. PN-EN 12280-1:2002. Rubber- or Plastics-Coated Fabrics—Accelerated Ageing Tests_Part 1: Heat Ageing; EN 12280-1:1997; International Organization for Standards: Geneva, Switzerland, 1997.

21. Walters, D.R.; Kingham, G. Biosynthesis inhibitors by barley seedlings: Effects of mildew infections. New Phytol. 1990, 114, 659-665. [CrossRef]

22. Fuller, S.; Gautam, A.A. Procedure for measuring microplastics using pressurised fluid extraction. Environ. Sci. Technol. 2016, 50, 5774-5780. [CrossRef]

23. Scopetani, C.; Esterhuizen-Londt, M.; Chelazzi, D.; Cincinelli, A.; Setälä, H.; Pflugmacher, S. Self-contamination from clothing in microplastics research. Ecotoxicol. Environ. Saf. 2020, 189, 110036. [CrossRef]

24. Botsoglou, N.A.; Fletouris, D.J.; Papageorgiou, G.E.; Vassilopoulos, V.N.; Mantis, A.J.; Trakatellis, A.G. Rapid, sensitive, and specific thiobarbituric acid method for measuring lipid peroxidation in animal tissue, food, and feedstuff Samples. J. Agric. Food Chem. 1994, 42, 1931-1937. [CrossRef]

25. Stüven, J.; Pflugmacher, S. Antioxidative stress response of Lepidium sativum due to exposure to cyanobacterial secondary metabolites. Toxicon 2007, 50, 85-93. [CrossRef]

26. Bradford, M.M. A rapid and sensitive method for the quantitation of microgram quantities of protein utilising the principle of protein-dye binding. Anal. Biochem. 1976, 72, 248-254. [CrossRef]

27. Aebi, H. Catalase in vitro. Methods Enzymol. 1984, 105, 121-126. [CrossRef] [PubMed]

28. Sokal, R.R.; Rohlf, F.J. Biometry. In The Principles and Practice of Statistic in Biological Research; WH Freeman and Company: New York, NY, USA, 1997.

29. Atta, B.M.; Mahmood, T.; Trethowan, R.M. Relationship between root morphology and grain yield of wheat in North-Western NSW, Australia. Aust. J. Crop. Sci. 2013, 7, 2108-2115. [CrossRef]

30. Walter, A.; Schurr, U. Dynamics of leaf and root growth: Endogenous control versus environmental impact. Ann. Bot. 2005, 95, 900-981. [CrossRef] [PubMed]

31. Lynch, J.P. Steep, cheap and deep: An ideotype to optimise water and N acquisition by maise root systems. Ann. Bot. 2013, 112, 347-357. [CrossRef] [PubMed] 
32. Liao, M.; Palta, J.A.; Fillery, I.R.P. Root characteristics of vigorous wheat improve early nitrogen uptake. Aust. J. Agr. Res. 2006, 57, 1097-1107. [CrossRef]

33. Palta, J.A.; Fillery, I.R.P.; Rebetzke, G.J. Restricted-tillering wheat does not lead to greater investment in roots and early nitrogen uptake. Field Crop Res. 2007, 104, 52-59. [CrossRef]

34. Pflugmacher, S. Promotion of oxidative stress in the aquatic macrophyte Ceratophyllum demersum during biotransformation of the cyanobacterial toxin microcystin-LR. Aquat. Toxicol. 2004, 70, 169-178. [CrossRef]

35. Manikowski, H.; Jurga, J. Free radicals in plastic food containers. Mater. Sci. 2003, 9, 206-208.

36. Fotopoulou, K.; Karapanagioti, H. Degradation of various plastics in the environment. In Hazardous Chemicals Associated with Plastics in the Marine Environment; Takada, H., Karapanagioti, H.K., Eds.; Springer: Berlin/Heidelberg, Germany, 2017. [CrossRef]

37. Esterhuizen-Londt, M.; Pflugmacher, S.; Downing, T.G. The effect of $\beta$-N-methylamino-L-alanine (BMAA) on oxidative stress response enzymes of the macrophyte Ceratophyllum demersum. Toxicon 2011, 57, 803-810. [CrossRef]

38. Pflugmacher, S.; Tallinen, S.; Kim, Y.J.; Kim, S.; Esterhuizen, M. Ageing affects microplastic toxicity over time: Effects of aged polycarbonate on germination, growth, and oxidative stress of Lepidium sativum. Sci. Total Environ. 2021, 790, 148166. [CrossRef]

39. Yu, P.; Liuz, Z.; Wu, D.; Chen, M.; Lv, W.; Zhao, Y. Accumulation of polystyrene microplastics in juvenile Eriocheir sinensis and oxidative stress effects in the liver. Aquat. Toxicol. 2018, 200, 28-36. [CrossRef]

40. Oliveira, P.; Barboza, L.G.A.; Branco, V.; Figueiredo, N.; Carvalho, C.; Guilhermino, L. Effects of microplastics and mercury in the freshwater bivalve Corbicula fluminea (Müller, 1774): Filtration rate, biochemical biomarkers and mercury bioconcentration. Ecotox. Environ. Saf. 2018, 164, 155-163. [CrossRef] [PubMed]

41. Barboza, L.G.A.; Vieira, L.R.; Branco, V.; Carvalho, C.; Guilhermino, L. Microplastics increase mercury bioconcentration in gills and bioaccumulation in the liver, and cause oxidative stress and damage in Dicentrarchus labrax juveniles. Sci. Rep. 2018, 8, 15655. [CrossRef]

42. Tripathy, B.C.; Oelmüller, R. Reactive oxygen species generation and signaling in plants. Plant Signal. Behav. 2012, 7, 1621-1633. [CrossRef]

43. Tsukagoshi, H.; Busch, W.; Benfey, P.N. Transcriptional regulation of ROS controls transition from proliferation to differentiation in the root. Cell 2010, 143, 606-616. [CrossRef]

44. Gray, W.M.; Kepinski, S.; Rouse, D.; Leyser, O.; Estelle, M. Auxin regulates SCFTIR1-dependent degradation of AUX/IAA proteins. Nature 2001, 414, 271-276. [CrossRef] [PubMed]

45. Machado, A.A.D.S.; Lau, D.W.; Kloas, W.; Bergmann, J.; Bachelier, J.B.; Faltin, E.; Becker, R.; Görlich, A.S.; Rillig, M.C. Microplastics can change soil properties and affect plant performance. Environ. Sci. Technol. 2019, 53, 6044-6052. [CrossRef] [PubMed]

46. Pflugmacher, S.; Huttunen, J.; van Wolf, M.; Kim, Y.; Kim, S.; Mitrovic, S.; Esterhuizen-Londt, M. Enchytraeus crypticus avoid soil spiked with microplastic. Toxics 2020, 8, 10. [CrossRef] [PubMed]

47. Lehmann, A.; Leifheit, E.F.; Feng, L.; Bergmann, J.; Wulf, A.; Rillig, M.C. Microplastic fiber and drought effects on plants and soil are only slightly modified by arbuscular mycorrhizal fungi. Soil Ecol. Lett. 2020, 1-13. [CrossRef]

48. Rushton, B.M.; Salomons, N.S. An investigation of factors relating to the exudation of polyester plasticisers from poly(vinyl) chloride. J. Appl. Polym. Sci. 1969, 13, 2341-2358. [CrossRef]

49. Madorsky, S.L. Thermal Degradation of Polymers; R.E. Kreiger: New York, NY, USA, 1975.

50. Anonymous. Thermal Degradation of Plastics; Zeus Industrial Products, Inc: Orangeburg, SC, USA, 2005; pp. 1-8.

51. Pospíšil, J.; Nešpůrek, S. Highlights in chemistry and physics of polymer stabilisation. Macromol Symp. 1997, 115, 143-163. [CrossRef]

52. Scalenghe, R. Resource or waste? A perspective of plastics degradation in soil with a focus on end-of-life options. Heliyon 2018, 4, e00941. [CrossRef] [PubMed]

53. Pflugmacher, S.; Sulek, A.; Mader, H.; Heo, J.; Noh, J.H.; Penttinen, O.-P.; Kim, Y.; Kim, S.; Esterhuizen, M. The influence of new and artificial aged microplastic and leachates on the germination of Lepidium sativum L. Plants 2020, 9, 339. [CrossRef] [PubMed] 